\title{
Effects of Changes in Source-Sink Relation in Different Planting Dates on Yield and Yield Components of Soybean Cultivars
}

\author{
Fatemeh Marzban \\ Islamic Azad University, Qaemshahr Branch, Iran
}

Esmaeil Yasari

Assistant Prof. Department of Agriculture, Payame Noor University, 19395-4697

Tehran, Iran

Omid Ghasemi

Agriculture and Natural Resources Research Center of Mazandaran Province, Iran

Hamid Reza Mobasser

Islamic Azad University, Qaemshahr Branch, Iran

Received: February 21, 2011 Accepted: March 10, 2011 doi:10.5539/ijb.v3n3p90

\begin{abstract}
Split-split plots experimental design based on randomized complete block design was conducted at the Baiekola Agricultural Research Center in 2010 to study the effects of changes in source-sink on the yield and yield components of soybean cultivars planted at different dates. Factors studied in this experiment included planting date, as the main plot, at two levels (June 6, June 27), cultivars (Line 032, 033, Sari or JK, and Telar or BP), as the sub plot, and five levels (including the removal of the top, the middle, and the bottom one thirds of the leaves, removal of one third of the flowers, and the control treatment as the sub-sub plot. Results of analysis of variation showed that the various cultivars were significantly different in all the studied traits at $(\mathrm{P}<0.01)$ probability level.

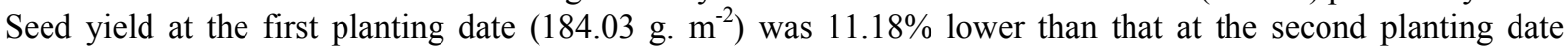
$\left(163.45 \mathrm{~g} \cdot \mathrm{m}^{-2}\right)$. The highest seed yield was obtained in Line 033 with $219.96 \mathrm{~g} \cdot \mathrm{m}^{-2}$, which was statistically different from the those of all the other cultivars except that of Line 032, which was 186.19 g.m ${ }^{-2}$. The higher seed yields in Line 033, as compared with other treatments, were accompanied by the highest 1000 seed weight $(242.93 \mathrm{~g})$, the highest number of pods per plant on the main stem (43.31) and on the auxiliary stems (33.37), and the relatively high number of seeds per pod (2.37). Results of applying limitations of the sink-source treatments on seed yield showed that the highest seed yield was obtained in the control treatment $\left(212.17 \mathrm{~g} \cdot \mathrm{m}^{-2}\right)$. With the removal of the top one third of the leaves, the yield decreased severely so that the least seed yield in this treatment $\left(138.08\right.$ g. $\mathrm{m}^{-2}$ ) was $35 \%$ less than that of the control. In the treatments of removing the middle one third of the leaves and one third of the flowers, the seed yield was reduced by 28.5 and $21.8 \%$, respectively, as compared with the control. The least effect on seed yield was observed in the treatment of removing the bottom one third of the leaves, in which the yield was $201 \mathrm{~g} . \mathrm{m}^{-2}$, or only $5.25 \%$ less than that of the control. The high yields in the control treatment of applying sink-source limitations were accompanied by high 1000 seed weight $(220.217 \mathrm{~g})$, the maximum number of seeds per pod (2.53), the maximum number of pods on the main stem (46.40), and, finally, the maximum number of pods per stem (74). The least seed yield in applying the treatment of the removal of the top one third of the leaves was also accompanied by the least 1000 seed weight (199.59 g), the fewest number of seeds per pod (2.27), the fewest number of pods per main stem (30.62), and the fewest number of pods per plant (53).
\end{abstract}

Keywords: Cultivar, Planting date, Seed yield, Sink-source, Soybean

\section{Introduction}

The crop plant soybean (Glycine max L. Merr) is one of the main sources of vegetable oil and protein, and ranks first in the world in vegetable oil production (Latifi, 1994). The genotype and the cultural and environmental 
factors are among factors that directly, or indirectly, influence seed and oil yield of this crop. Sala et al., (2007) stated that late planting shortens the growing season and the chance to better complete pod formation, and thus reduces the number of seeds per pod and the final seed yield. Furthermore, by finding out the part that the different plant organs play in the production of photosynthates, it becomes possible to take the necessary management steps at specific growth stages of the crop (Egli, 1999). Results of experiments carried out showed that by improving the relationships between sink and source, the seeds will fill well (Egli and Bruening, 2003). The mature leaves of the crop are the source and the growing organs are the sink (Hashemi Dezfooli et al., 1996; Emam and Niknazhad, 1988). The movement of photosynthates from the source to the sink, on the one hand, depends on the capacity to produce photosynthates at the source and, on the other hand, is dependent on the capacity of the sink to consume the photosynthates. If there is an imbalance between these two, the yield obtained will decrease. The reaction of various soybean varieties to the removal of leaves from the different levels of the canopy, and the ability to re-transport nutrients to the flowers and the seeds, can be considered as suitable traits in determining resistant varieties with high production potentials. Therefore, in order to determine the best varieties with respect to yield in spring and summer soybean crops, and to study the response of each variety studied to the application of source-sink limitations, the following experiment was conducted.

\section{Material and Methods}

An experiment in split-split plots in the format of randomized complete block design was conducted at the Agriculture Research Station of Baiekola to study the effects of changes in source-sink on the yield and yield components of spring and summer soybean varieties planted at different dates. The planting date was considered as the main plots at two levels (June 6 and June 27), and variety and the application of source-sink limitations at four levels (Line 033, Line 032, Sari or JK, and Telar or BP) and at five levels (removal of the top, the middle, and the bottom one thirds of leaves, the removal of one third of the flowers, and the control treatment) were considered as the sub plot and the sub-sub plots, respectively. Experimental plots were 6 meters long, each with seven seed rows 45 centimeters apart. All the planting, maintenance, and harvesting operations were carried out according to the technical instructions issued by the Agriculture and Natural Resources Research Center of Mazandaran. Removal of the top, the middle, and the bottom one thirds of the leaves was carried out at the start of flowering. Necessary notes taken included the number of pods on the main stem, the number of pods on auxiliary stems, the number of seeds in pods, the 1000 seed weight, and the seed yield (obtained by omitting the boundary effects and through taking samples from the remaining part of each plot). Data analysis was performed using the MSTAT C statistical software; and comparison of means was evaluated on the basis of Duncans multiple range test at the level of $5 \%$ probability.

\section{Results and Conclusions}

1000 seed weight: results of variance analysis showed that the effects of cultivar and the application of source-sink limitations, and the effect of date of planting on 1000 seed weight, were significant at the one and five percent probability, respectively. The effects of other factors and those of their mutual relationships on 1000 seed weight were not significant. Comparison of the means showed that delays in planting the second crop (the summer crop) caused the 1000 seed weight to decrease by $35 \%$, as compared to delays in planting the first crop (the spring crop). Among the lines, 033 with 242.93 and 032 with $185.79 \mathrm{~g}$ showed the highest and the lowest 1000 seed weight, respectively. Results of applying source-sink limitations also revealed that the highest 1000 seed weight was obtained in the treatment of removing one third of the flowers $(234.66 \mathrm{~g})$ and the lowest in the treatment of removing the top one third of the leaves (199.59 g) (Table 1). Results obtained showed that the removal of one third of the flowers actually increased the source to sink ratio. Thus, each of the remaining sources had a bigger share in the sources remained; and, therefore, an increase in the 1000 seed weight was observed.

The number of seeds per pod: according to the results of the comparison of means, the number of seeds per pod in the first planting date was 2.56 , and delays in the second planting date reduced this number (2.26). The Line 032 and $\mathrm{JK}$, with averages of 2.59 and 2.19, had the highest and the lowest number of seeds per pod, respectively. The results obtained also suggested that by applying source-sink limitations, the highest number of seeds per pod was observed in the control treatment and the lowest in the treatment of removing one third of the flowers (2.27) (Table 1). This showed that the top leaves were effective in supplying the needed nutrients for the filling of seeds and in achieving higher seed yields, and that by removing these leaves it would be practically impossible for the crop to have a high seed yield. These results were consistent with those obtained by Egly and Bruening (2001).

The number of pods on the main stem: results of the experiment indicated there was a decrease in the number of pods on the main stem in the second date of planting (38.43) as compared to that in the first planting date 
(42.47), although this difference was not statistically significant. Comparison of the means also revealed that the highest number of pods on the main stem (43.31) was obtained in Line 033, and that Line 032 and BP and JK with 41.52, 37.25, and 39.72 ranked second to fourth, respectively. Results of applying source-sink limitations showed that the highest number of pods on the main stem was obtained in the control treatment with 46.4 pods, and that by removing the top leaves, this number decreased by $34 \%$, compared to the control, and reached 30.62 . These results also revealed that by removing the middle leaves of the plants, the number of pods on the main stem decreased by $12.7 \%$, as compared to the control.

The number of pods on the auxiliary stems: results obtained suggested that the number of pods on the auxiliary stems in the first planting date (27.11) was higher than that in the second date of planting (21.21), so that by delaying the planting date, the number of pods on the auxiliary stems decreased by $21.76 \%$. Among the cultivars, the highest number of pods on the auxiliary stems (33.37) was observed in Line 033 and the lowest in BP (15.56). By applying source-sink limitations, it was observed that the lowest number of pods on the auxiliary stems was obtained in the treatment of removing the middle leaves (19.62) and the highest in the treatment of removing the bottom leaves (27.09).

Seed yield per plant: results of this study revealed that seed yield per plant in the first planting date (184.031 g. $\left.\mathrm{m}^{-2}\right)$ was $11.18 \%$ higher than that of the second planting date $\left(163.45 \mathrm{~g} . \mathrm{m}^{-2}\right)$. The reduction in soybean seed yield due to delayed planting was reported by Thomas (1990) from eastern United States, by Yasari et al. (2009) from Mazandaran, and by Rabiee et al. (2005) from Gilan. Comparison of seed yields in the different treatments showed that the highest yield was obtained in Line 033 with $219.96 \mathrm{~g} . \mathrm{m}^{-2}$, which was statistically different from those of other varieties, except from that of Line 032 with 186.19 g.m $\mathrm{m}^{-2}$. Results obtained suggested that the higher seed yields in Line 033, as compared to the other treatments, were accompanied by the highest 1000 seed weight (242.93 g), the highest number of pods on the main stem (43.31) and on the auxiliary stems (33.37), and the relatively high number of seeds per pod (2.37). The results also revealed that the lowest seed yield observed in the variety BP (126.41 g.m $\mathrm{m}^{-2}$ ) was accompanied by the lowest number of pods on the auxiliary stems (15.56), the relatively low weight of 1000 seeds $(217.27 \mathrm{~g})$, and the lower number of pods on the main stems (39.72).

Results of the effects of applying the limitations of the source-sink treatments on seed yield showed that the highest seed yield was obtained in the control treatment $\left(212.17 \mathrm{~g} . \mathrm{m}^{-2}\right)$. Removal of the top leaves severely reduced seed yield so that the lowest seed yield was obtained in this treatment $\left(138.08 \mathrm{~g} . \mathrm{m}^{-2}\right)$, which was $35 \%$ lower than that of the control. This shows the very substantial role of the top leaves of the stem in supplying the photosynthetic assimilates and in achieving high seed yields per plant. Results obtained also indicated that, after the treatment of removing the top leaves, the treatment of removing the middle leaves caused the highest decrease in seed yield per plant (151.61 g. $\left.\mathrm{m}^{-2}\right)$, which was $28.5 \%$ lower than that of the control. Removal of one third of the flowers caused the seed yield to be $165.85 \mathrm{~g} . \mathrm{m}^{-2}$, which was $21.8 \%$ lower than that of the control; and finally, the least effect of yield reduction was that of the treatment of removing the bottom leaves, in which the yield was $201 \mathrm{~g} . \mathrm{m}^{-2}$, which showed a reduction of only $5.25 \%$ compared to that of the control. This shows that the lower leaves of the stems have the least effect in supplying the photo-assimilates and in achieving high yields _ something that was also observed in the studies Zhu et al. (2004) conducted on wheat. Results obtained also indicate that the high yields in the control treatment of applying limitations on the source-sink were accompanied by high 1000 seed weight $(220.217 \mathrm{~g})$, by the maximum number of seeds per pod (2.53), by the maximum number of pods on the main stem (46.40), and, finally, by the highest number of pods on stems (74). The least seed yield obtained in the treatment of removing the top leaves was also accompanied by the lowest 1000 seed weight (199.59 g), the lowest number of seeds per pod (2.27), the lowest number of pods on the main stem (30.62), and the lowest number of pods per plant (53) (Table 1).

\section{General Conclusions}

Results obtained in this experiment showed that by delaying the planting date, the yield and the yield components decreased. Line 033 was the best with regard to seed yield and yield components. Applying limitations on source-sink also affected yield and yield components. As a whole, Line 033 in the first planting date, the control treatment (without removing leaves and flowers), and the treatment of removing the bottom one third of the leaves had the highest yield, and after them came Line 032 in the first planting date and the control treatment; the least seed yield was observed in the variety BP and in the treatment of removing the top one third of the leaves.

\section{References}

Egli, D.B. (1999). Variation in leaf starch and sink limitations during seed filling in soybean. Crop Science, 39(5): 1361-1368. 
Egli, D.B., and W.P .Bruening. (2001). Potential of early-maturity soybean cultivars in late planting. Agron. J, . 92: 532-537.

Egli, D.B. and W.P. Bruening. (2003). Increasing sink size does not increase photosynthesis during seed filling in soybean. European Journal of Agronomy, 19(2): 289-298.

Hashemi Dezfooli, Abolhassan; Koochaki, A.; Banayan, M. (1996). Crop Plant Yield Increase, Mashhad University Jihad Publications (second edition) Pp 287.

Imam, Yahya and M. Niknezhad. (1995). Introduction to plant physiology (first edition), Shiraz University Publications, Pp 571.

Latifi, N. (1994). Soybean cultivation, Mashhad University Jihad Publications Pp 295.

Rabiee, M, Karimi, M and Safa, F. (2005). Study of the effects of date of sowing on yield and agronomic traits of soybean cultivars in rotation after wheat in Khouzastan. Iranian Journal of Agronomy, 35(1): 181-188.

Sala, R.G., M.E. Westgate and F.H. Andrade. (2007). Source/sink ratio and the relationship between maximum water content, maximum volume, and final dry weight of maize kernels. Field Crops Research, 101(1): 19-25.

Thomas, D. L. (1990). Planting date effect and double cropping potential of soybean in the south eastern U.S. Applied Agriculture Research, 1(3): 205-211.

Yassari, E. Mozafari, S and Shafiee, e and Foroutan, A. (2009). Evaluation of Sink-source Relationship of Soybean Cultivars at Different Dates of Sowing. Research Journal of Agriculture and Biological Sciences, 5(5): 786-793.

Zhu, G. X., Midmore. D. J., Radford. B. J., Yule. D. F. (2004). Effect of timing of defoliation on wheat (Triticum aestivum L.) in central Queensland. Field Crop Research, 88: 211-226.

Table 1. Comparison of the means of yield and yield components as affected by planting dates, varieties, and limitations on source - sink

\begin{tabular}{|c|c|c|c|c|c|}
\hline Treatment & $\begin{array}{l}\text { Seed yield per } \\
\text { plant }\left(\mathrm{g} \cdot \mathrm{m}^{-2}\right)\end{array}$ & $\begin{array}{l}1000 \text { seed } \\
\text { weight }(\mathrm{g})\end{array}$ & $\begin{array}{l}\text { Number of } \\
\text { seeds per pod }\end{array}$ & $\begin{array}{l}\text { Number of pods on } \\
\text { auxiliary stems }\end{array}$ & $\begin{array}{l}\text { Number of pods on } \\
\text { the main stem }\end{array}$ \\
\hline \multicolumn{6}{|l|}{ Planting date } \\
\hline A1: May 27 & $184.031 \mathrm{a}$ & $221.540 \mathrm{a}$ & $2.563 \mathrm{a}$ & $27.115 \mathrm{a}$ & $42.476 \mathrm{a}$ \\
\hline A2: July 7 & $163.458 \mathrm{a}$ & $214.767 \mathrm{~b}$ & $2.266 \mathrm{~b}$ & $21.219 \mathrm{a}$ & $38.430 \mathrm{a}$ \\
\hline \multicolumn{6}{|l|}{ Varieties } \\
\hline B1: Line 032 & $186.193 \mathrm{ab}$ & $185.797 \mathrm{c}$ & $2.598 \mathrm{a}$ & $29.025 \mathrm{a}$ & $41.521 \mathrm{a}$ \\
\hline B2: Line 033 & $219.969 \mathrm{a}$ & $242.933 \mathrm{a}$ & $2.371 \mathrm{~b}$ & $33.372 \mathrm{a}$ & $43.318 \mathrm{a}$ \\
\hline B3: Variety JK & $162.425 \mathrm{~b}$ & $226.613 \mathrm{~b}$ & $2.197 \mathrm{c}$ & $18.710 \mathrm{~b}$ & $37.251 \mathrm{a}$ \\
\hline B4: Variety BP & $126.411 \mathrm{c}$ & $217.271 \mathrm{~b}$ & $2.492 \mathrm{ab}$ & $15.560 \mathrm{c}$ & $39.723 \mathrm{a}$ \\
\hline \multicolumn{6}{|c|}{ Source and sink limitations } \\
\hline $\begin{array}{l}\text { Removing the top } 1 / 3 \\
\text { of leaves:C1 }\end{array}$ & $138.082 \mathrm{~b}$ & $199.596 \mathrm{c}$ & $2.270 \mathrm{c}$ & $22.988 \mathrm{c}$ & $30.620 \mathrm{c}$ \\
\hline $\begin{array}{l}\text { Removing the middle } \\
1 / 3 \text { of leaves:C2 }\end{array}$ & $151.615 \mathrm{~b}$ & $214.013 \mathrm{~b}$ & $2.360 \mathrm{bc}$ & $19.624 \mathrm{a}$ & $40.507 \mathrm{~b}$ \\
\hline $\begin{array}{l}\text { Removing the bottom } \\
1 / 3 \text { 0f leaves: C } 3\end{array}$ & $201.026 \mathrm{a}$ & $222.275 \mathrm{ab}$ & $2.470 \mathrm{ab}$ & $27.090 \mathrm{ab}$ & $42.116 \mathrm{ab}$ \\
\hline $\begin{array}{lll}\begin{array}{l}\text { Removing } \\
\text { flowers:C4 }\end{array} & 1 / 3 \quad \text { of } \\
\end{array}$ & $165.853 \mathrm{~b}$ & $234.668 \mathrm{a}$ & $2.435 \mathrm{ab}$ & $23.263 \mathrm{ac}$ & $42.615 \mathrm{ab}$ \\
\hline Control: C5 & $212.173 \mathrm{a}$ & $220.217 \mathrm{ab}$ & $2.537 \mathrm{a}$ & $27.868 \mathrm{a}$ & $46.408 \mathrm{a}$ \\
\hline
\end{tabular}

Figures with similar letters in each column and for each treatment are not significantly different statistically at the $5 \%$ probability level on the basis of Duncans multiple range test 